\title{
Antimicrobials in foods today and the role of chitosan - current hopes and new perspectives
}

\section{Salvatore Parisi* \\ Industrial Consultant, Palermo, Italy}

At present, the food industry faces different challenges with relation to food safety, public hygiene, and new regulatory norms on the international level [1-3]. Many of these matters concern the nature of foods and beverages in terms of chemical contamination, chemical and physical features (with relation to artisanal products and new or "ameliorated" industrial versions), microbiological contamination, detection of foreign matters, intentional food adulteration, traceability, sustainability, etc. [4-6]. However, one of these arguments at least is not immediately recognized by food consumers because of the clear connection with non-food industries: the contamination and the allowed or unallowed use by antimicrobial substances for food production purposes.

Actually, the use of antibiotics and similar compounds in this ambit is well known and a vast literature is now available when speaking of the correlated risk in terms of human health [7]. Two basic consequences are observed when speaking of antimicrobials in foods: the psychological impact of these compounds on the behaviour of food consumers on the one side, and the real effects on human health. Practically, the problem is the selection of resistant mutant life forms in foods because of the intensive use of antibiotic, even at low dosages: risks could be minimized depending of the usage, but the theoretical danger is always possible. For these reasons, risk assessment is surely needed in these food-related ambits. Many different products - raw milk cheeses, cured sausages, market vegetables, etc.) can show similar resistant microorganisms (enterococci, staphylococci, lactococci, coliforms) $[7,8]$. Because of the possible transfer of mutant and resistant life forms from animals or vegetables to the human being, common technological measures against microbial spreading and pathogen attacks may be not sufficient [9]. For these reasons, risk assessment studies could suggest the elimination of antibiotics in animals; however, several researchers have recently considered that the effect of similar actions could be detrimental for animals and the human health without advantages when speaking of safe foods. On the other side, the careful and reliable monitoring of antimicrobial usages in the food production should give better results $[7,8]$. Anyway, alternative systems for the eradication of most dangerous infections are needed [10].

One of the most recent innovations in this ambit is the use of chitosan in certain food productions, including also the management of food production areas (work surfaces for sanitation purposes) and the creation of innovative packaging materials. Chitosan, chemically a group of deacetylated polymers (origin: the natural mucopolysaccharide chitin), can be used as an antimicrobial agent. Actually, this compound may be also used as a flocculating and encapsulating agent. It may act as an aqueous thickener and a gelling additive. For these reasons, chitosan may be used in the industry of foods, as an additive for cosmetics, for water treatments, as a component for biomedical devices, etc. [11-
15]. Interestingly, chitosan may be also act as a synergic antimicrobial in conjunction with other known antibiotics such as amikacin or gentamicin $[14,16]$.

The action spectrum of this substance is broad: it can inhibit the spreading of a large group of microbial agents including $L$. monocytogenes (a remarkable representative pathogen and the 'Enemy No. One' in the food ambit) and fungal life forms, degradative organisms able to produce very important neurotoxins. On these bases, it could be deduced that chitosan has a bright future when speaking of food and food packaging technologies and applications (surface sanitization against biofilms; realization of antimicrobial packaging materials; food preservative; etc.). On the other side, the use of chitosan may be still questionable in these ambits: at present, there are only a few data concerning toxicological aspects and safety evaluations of this versatile antimicrobial in foods [17]. Consequently, more research is needed.

\section{References}

1. Parisi S (2016) The World of Foods and Beverages Today: Globalization, Crisis Management and Future Perspectives.

2. Parisi S, Barone C, Sharma RK (2016) Chemistry and Food Safety in the EU: The Rapid Alert System for Food and Feed (RASFF). Springer briefs in chemistry of foods, springer international publishing, Cham.

3. Pisanello D (2014) Chemistry of Foods: EU legal and regulatory approaches. springer briefs in chemistry of foods, springer international publishing, cham.

4. Delgado A, Parisi S, Barone C, Almeida V (2016) Leguminosas na dieta mediterranica nutricao, seguranca, sustentabilidade. Conferencia de Inovacao e Seguranca Alimentar, Instituto Politécnico de Leiria, Portugal.

5. Mania I, Barone C, Caruso G, Delgado A, Micali M, Parisi S (2016) Traceability in the Cheesemaking Field. The Regulatory Ambit and Practical Solutions. Food Qual Mag 3: 10-20.

6. Mania I, Fiorino M, Barone C, Barone M, Parisi S (2016) Traceability of Packaging Materials in the Cheesemaking Field. The EU Regulatory Ambit. Food Packag Bull 25, 4\&5:11-16.

7. Phillips I1, Casewell M, Cox T, De Groot B, Friis C, et al. (2004) Does the use of antibiotics in food animals pose a risk to human health? A critical review of published data. J Antimicrob Chemother 53: 28-52. [Crossref]

8. Perreten V, Schwarz F, Cresta L, Boeglin M, Dasen G, et al. (1997) Antibiotic resistance spread in food. Nature 389: 801-802. [Crossref]

9. Parisi S (2002) Profili evolutivi dei contenuti batterici e chimico-fisici in prodotti lattiero-caseari. Industrie Alimentari 41, 412:295-306.

Correspondence to: Salvatore Parisi, Industrial Consultant, Palermo, Italy, E-mail: drparisi@inwind.it

Received: December 22, 2016; Accepted: January 19, 2017; Published: January 23, 2017 
10. Stanton TB (2013) A call for antibiotic alternatives research. Trends Microbiol 21: 111113. [Crossref]

11. Altieri C, Scrocco C, Sinigaglia M, Del Nobile MA (2005) Use of chitosan to prolong mozzarella cheese shelf life. J Dairy Sci 88: 2683-2688. [Crossref]

12. Del Nobile MA, Gammariello D, Conte A, Attanasio M (2009) A combination of chitosan, coating and modified atmosphere packaging for prolonging Fior di latte cheese shelf life. Carbohydr Polym 78: 151-156.

13. Goosen MF (Ed) (1996) Applications of Chitan and Chitosan. CRC Press, Boca Raton.

14. Mu H, Guo F, Niu H, Liu Q, Wang S, Duan J,et al. (2014) Chitosan improves anti- biofilm efficacy of gentamicin through facilitating antibiotic penetration. Int $\mathrm{J} \mathrm{Mol} \mathrm{Sci}$ 15: 22296-22308.

15. Granda CX, Pan FI, Jaime I, Rovira J, Maté JI (2016) Improvement of the microbiological quality of ready-to-eat peeled shrimps (Penaeusvannamei) by the use of chitosan coatings. Int J Food Microbiol 232: 144-149.

16. Mu H, Zhang A, Zhang L, Niu H, Duan J (2014) Inhibitory effects of chitosan in combination with antibiotics on Listeria monocytogenes biofilm. Food Control 38 215-220

17. Luo Y, Wang Q (2013) Recent advances of chitosan and its derivatives for novel applications in food science. J Food Process Beverages 1: 1-13.

Copyright: (2017 Tsabang N. This is an open-access article distributed under the terms of the Creative Commons Attribution License, which permits unrestricted use, distribution, and reproduction in any medium, provided the original author and source are credited. 